\author{
过内和 人* $^{*}$
}

\title{
Relationship between Clinical Sensory Deficit and Posterior Tibial Nerve Somatosensory Evoked Potentials (SEP) in Stroke Patients
}

\author{
Kazuhito TsuJIUchI*
}

\begin{abstract}
Clinical studies have consistently demonstrated that SEP abnormalities are associated with sensory deficits of joint position, touch, vibration, and stereognosis. However, when we try to use SEP as an objective method of sensory testing, it is difficult to evaluate the degree of SEP waveform abnormalities with conventional methods. The purpose of this study was to determine the usefulness of tibial nerve SEP as an objective method of sensory testing when the interside ratio of sum of squares for SEP waveform analysis was used. We obtained the SEP data and the sensory data in 100 stroke patients (age $=59.3 \pm 10.5$, median duration of stroke 124 days), and as normative data, in 35 volunteer subjects (age $=29 \pm 7.2$ ) for SEP and in 21 volunteer subjects (age $=38.9 \pm 14.5$ ) for sensation. The SEP traces were obtained by stimulating the tibial nerve at the ankle on the right side and the left side alternately with an electric pulse. The stimulus intensity was adjusted to produce a good muscle twitch in the abductor hallucis. Thousand sweeps were averaged for each recording and each stimulus side. A complete sweep consisted of 2,000 samples, representing $200 \mathrm{~ms}$ of time. The scalp recordings were obtained with the recording electrode at the $C^{\prime} z$ scalp location referred to bilateral earlobes. The interside ratios of sum of squares were calculated using the latency samples between P 35 and P 53 evoked by unaffected and affected side stimulation. Based on the mean and SD of the natural logarithm of the interside ratios of sum of squares for normal subjects, the SEP waveforms in stroke patients were divided into four grades according to the amount of decrease in the interside ratio of sum of squares. We compared the SEP waveform grades to kinetic senses, tactile senses and pain sensations. For statistical analysis, we calculated Spearman's rank order correlation coefficients between the SEP waveform grades and the degrees of sensory deficits. As a result, the correlation coefficients were 0.73 for kinetic senses, 0.46 for tactile senses and 0.23 for pain sensations. The sensitivity and the specificity of this SEP waveform analysis for detecting kinetic sensory deficits were 85 percent and 81 percent respectively. In conclusion, the interside ratio of sum of squares was a useful parameter to analyze the tibial nerve SEP waveform and to evaluate kinetic senses. (Jpn J Rehabil Med 2000 ; 37 : 274-281)
\end{abstract}

要 旨：脳血管障害患者 100 名において, 脛骨神経 SEP から得られた P 35 から P 53 まで の平方和の比と, 運動覚, 触覚, 痛覚の障害の程度の比較を行い, 脛骨神経 SEP がどの程度, 下肢感覚機能の評価に利用できるかを検討した。 その結果, 平方和の比は, 母趾運動覚と最も 相関が高く（Spearmanの順位相関係数 0.73）, 運動覚と触覚が解離した例の検討でも, 平方 和の比は触覚より運動覚との関連が高かった. SEP を運動覚の検査法として見ると，運動覚 障害の有無については感度 85\%, 特異度 81\%であり, 重度障害の有無についても感度 $73 \%$, 特異度 $90 \%$ となり感覚機能の評価法として利用できることが結論づけられた.(リハ医学 $2000 ; 37: 274-281$ )

Key words : 体性感覚誘発電位（somatosensory evoked potentials）, 脳卒中（stroke）, 感覚障害 (sensory disturbance)

1999 年 11 月 4 日受付, 2000 年 4 月 14 日受理

* 慶應義塾大学医学部リハビリテーション医学教室/テ 160-8582 東京都新宿区信濃町 35

Department of Rehabilitation Medicine, Keio University School of Medicine 


\section{はじめに}

脸血管障害患者のリハビリテーションにおける機能 評価では歩行動作などの運動機能とあわせて感覚機能 の評価も重要である.しかし, 認知面に問題のある患 者では, 感覚機能の評価は決して容易なものではな い. 体性感覚誘発電位 (somatosensory evoked potentials : 以下 SEP) は, 運動覚（他動的に関節を 動かした時の感覚）や位置覚（静的な関節の位置の感 覚）など内側毛帯系の感覚との関連が強いことが多く の研究者により報告されており ${ }^{1 \sim 6)}$, 感覚障害を, 認 知障害などにかかわりなく客観的に評価できる可能性 がある、しかし, 従来の研究では, 障害の有無との関 係は検討しているものの, 障害の程度との関係を検討 したものはほとんどない.

そこで今回，脳血管障害患者において，感覚障害の 程度を触覚, 運動覚, 痛覚のそれぞれについて臨床的 に 5 段階で評価したものと, 脛骨神経 SEP 波形の平 方和の比を利用した 3 段階の障害度とを比較して, 両 者の障害程度に関連があるかを検討したので若干の考 察と併せて報告する。

\section{対象および方法}

\section{1. 対 象}

対象とした患者は，東京都リハビリテーション病院 に入院中の脳血障害患者 100 名（男性 61 人，女性 39 人）で，平均年噛は $59.3 \pm 10.5$ 歳であった。患者の 選択にあたっては, 両側性病変, 未梢神経, 脊髄病変 の合併を疑わせる既往，所見を有するものは除外し た.また，感覚機能の測定時に非麻痺側でも計測を行 い, 正確な応答が得られた患者のみを選択した。被験 者には，あらかじめ本研究の目的抢よび内容を説明し たうえで，参加の同意を得た。

診断はすべての症例について, 病歴, 神経学的所
見, 頭部 CT 所見から行った. 内訳は, 脳出血 55 名, 脳梗塞 42 名, クモ膜下出血 2 名, 脳動静脈奇形 1 名 であった。障害側は右半球損傷 65 名, 左半球損傷 35 名であった，症例の発症から SEP 検查までの期間は 中央值 124 日（24〜416 日）であった。

\section{2. 下肢の感覚機能評価}

感覚機能の評価は, 患者麻痺側で運動覚, 触覚, 痛 賞について行った。

運動覚は, 他動的に母趾 MP 関節を底背屈させる ことにより，5段階で評価した．正常：10 度の動きを 正しく答えられる, 軽度低下：10 度の動きは間違え るが, 30 度の動きなら正しく分かるもの, 中等度低 下 : 30 度の動きでも間違えるが, 全可動域なら正し く答えられるもの, 重度低下：方向は分からないが, 動いているかいないかが正しく分かるもの, 脱失：動 いていることがまったく分からないものとした。

触覚はセメス・ワインスタイン・モノフィラメント 知覚テスター（North Coast Medical 社製）を使用 し，母趾指腹で閾值を計測し，障害の程度を 5 段階で 評価した（表 1 ).

痛覚は $1 \mathrm{~g}$ から $20 \mathrm{~g}$ まで測れる痛覚計（ユフ精器 社製，定量知覚針）を使用し，母趾先端部で計測し， 5 段階で評価した（表 1 ).

\section{3. 脛骨神経 SEP 検查}

SEP 検査は, 被検者が安静を保てるように周囲か ら隔絶したシールドルームで, 室温を $20^{\circ} \mathrm{C}$ に調整し 施行した. 被検者には, ベッド上で閉眼覚醒状態を保 つように指示した。計測には日本光電社製ニューロパ ック $8^{\circledR}$ を使用し, 脛骨神経を足関節部で左右交互に $2 \mathrm{~Hz}$ で電気刺激を行い, 両側耳架を基準電極とし, 国際 10-20 法に従い C’Z で, 潜時が $190 \mathrm{~ms}$ までの波 形を記録した（図 1). 周波数応答は $2 \sim 2,000 \mathrm{~Hz}$ で, 左右それぞれの刺激ごとに 1,000 回ずつ加算平均し た.再現性をみるため, 2 回施行した。電気刺激の強

表 1 感覚機能障害度分類

\begin{tabular}{cccccc}
\hline 感覚機能障害度分類 & 正常 & 軽度低下 & 中等度低下 & 重度低下 & 脱失 \\
\hline 運動覚 & $10^{\circ}$ を知覚 & $30^{\circ}$ を知覚 & $\begin{array}{c}\text { 全可動域 } \\
\text { を知覚 }\end{array}$ & $\begin{array}{c}\text { 動きの } \\
\text { み知覚 }\end{array}$ & $\begin{array}{c}\text { 動きを知 } \\
\text { 覚せず }\end{array}$ \\
\hline 触覚 $\left(\log _{10} F\right)$ & $\leqq 4.19$ & $\leqq 5.04$ & $\leqq 5.89$ & $\leqq 6.65$ & $6.65<$ \\
\hline 痛覚 $(\mathrm{g})$ & $\leqq 10$ & $\leqq 13$ & $\leqq 17$ & $\leqq 20$ & $20<$ \\
\hline
\end{tabular}

触覚における $F$ は，モノフィラメント知覚テスターで加えた力を $\mathrm{mg}$ 単位で計測 し，それに 10 をかけたものである。各テスターには $\log _{10} F$ の值が示されている。 
度は，母趾に明らかな動きの認められる強度とした。 計測された波形データはフロッピーディスクに記録保 存した。脛骨神経 SEP 波形は以下に示すような方法 で分類した。すなわち，記録された波形デー夕を科学 計算ソフト Matlab for Windows ${ }^{\circledR}$ (Mathworks 社 製）に取り込み，健側刺激により得られた C'zでの波 形上で P 35，P 53 を指定し，その区間での平方和 （健側刺激時の平方和）を計算した。同時に，健側で 指定した P 35，P 53 と同じ潜時の間での, 患側刺激 時の波形データの平方和（患側刺激時の平方和）を求 め, 健側刺激時の平方和に対する患側刺激時の平方和 の比を算出し（図 2), SEP の障害度を 3 段階に分類 した（表 2).

\section{4. 予備実験}

表 1 に示した感覚機能障害度分類は以下に示す予備 実験から算出した。健常な成人 21 名（男性 13 名, 女 性 8 名, 平均年齢 $38.9 \pm 14.5$ 歳）の 42 肢において本 試験と同様に運動賞, 触覚および痛覚閾値を計測し た.その結果, 運動覚については, 健常成人ではいず れも 10 度の他動運動を知覚できたため, それを基に 表 1 のように段階的に評価を行った。背屈, 底屈とも どちらも正確に答えられた段階で評価した。触覚にお いては平均值が $3.34 \pm 0.42 \log _{10} F$ となった。平均值

表 2 SEP 障害度分類

\begin{tabular}{cccc}
\hline SEP 障害度分類 & 正常 & 軽度障害 & 重度障害 \\
\hline 平方和の比 & $\geqq 0.25$ & $\geqq 0.061$ & $0.061>$ \\
\hline
\end{tabular}

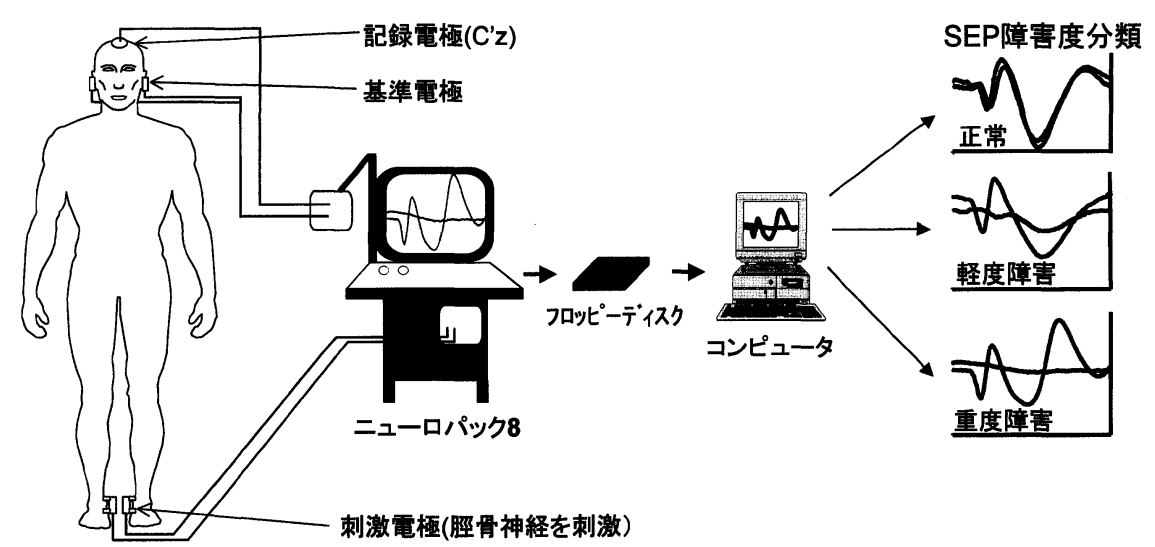

図 1 脛骨神経 SEP の計測および評価

$\mathrm{C}^{\prime} z$ で計測された SEPデータからコンピュータにより平方和の比を算出し, それをもとに SEP 波形を正常, 軽度障害, 重度障害に分類した。

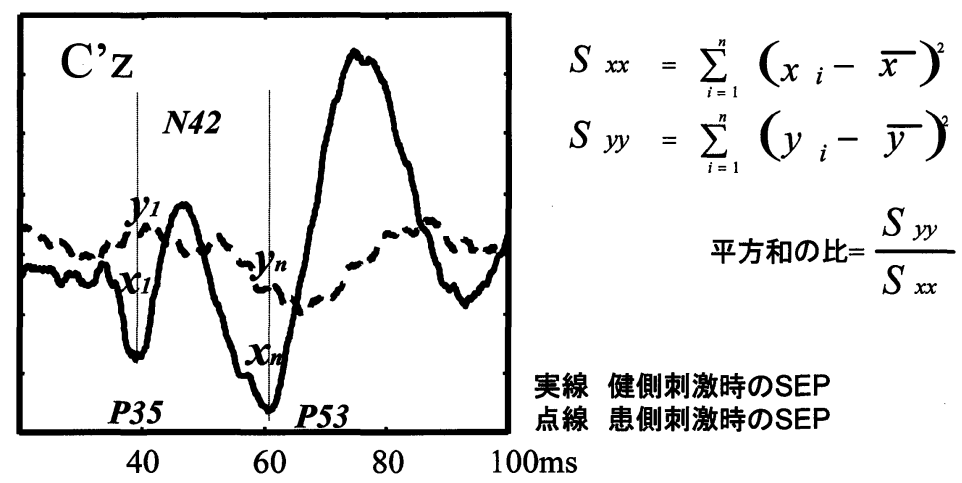

図 2 脛骨神経の SEP の波形分析法

健側刺激時の SEP 波形上の P 35 から P 53 までの区間のデータと, 同じ潜時 の患側刺激時のデータから, それぞれ平方和を求め, その比を算出すること で平方和の比を算出し, 患側健側を比較するための指標とした. 
から 2 標準偏差の間隔で, 正常, 軽度低下, 中等度低 下，重度低下とし，脱失については，計測上の最大刺 激を加えても感じられない範囲とした，痛党では，平 均値は $3.4 \pm 3.4 \mathrm{~g}$ となった。平均值から 2 標準偏差 までの範囲を正常とし, 障害の程度は上限までを 1 標 準偏差の間隔で分類した。

表 2 の SEP 障害度分類は, 健常成人 35 名（男性 28 名, 女性 7 名), 平均年齢 $29.0 \pm 7.2$ 歳に対して行 った予備実験より算出した。本実験と同様に脛骨神経 SEP を測定し，右側刺激による C’z 波形上で P 35, P 53 を指定し平方和（右側刺激時の平方和）を計算 するとともに，同じ潜時で左側刺激時の平方和も計算 し，右刺激時の平方和に対する左側刺激時の平方和の 比を算出した。健常成人右側刺激時の頂点潜時の平均 值は P 35 で $37.1 \pm 1.85 \mathrm{~ms}, \mathrm{~N} 42$ で $46.6 \pm 3.1 \mathrm{~ms}$, P 53 で $59.3 \pm 2.5 \mathrm{~ms}$ となり, 振幅の平均値は P 35$\mathrm{N} 42$ で $4.1 \pm 2.1 \mu \mathrm{V}, \mathrm{N} 42-\mathrm{P} 53$ で $4.1 \pm 1.9 \mu \mathrm{V}$ で あった。平方和については最小 74.4 , 最大 3112.3 , 中央值 379.2 , 平均值 $616.0 \pm 581.7$ であった。平方 和の比の分布は図 3 上段のようになり（横軸を平方和 の比の自然対数で表示), 平方和の比の自然対数の平 均は 0.02 , 標準偏差 0.71 となった. 平均值から 2 標 準偏差ごとに正常, 軽度障害, 重度障害の 3 段階に分 類することにした。この結果，SEP 障害度分類の基 準は, 平方和の比の值によって, 正常が 0.25 以上,
軽度障害が 0.061 以上 0.25 未満, 重度度障害が 0.061 未満となった（表 2 ).

\section{5. 統計的検討}

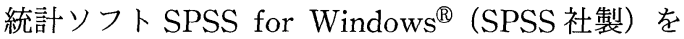
使用し, 健常成人で得られた脛骨神経 SEP の平方和
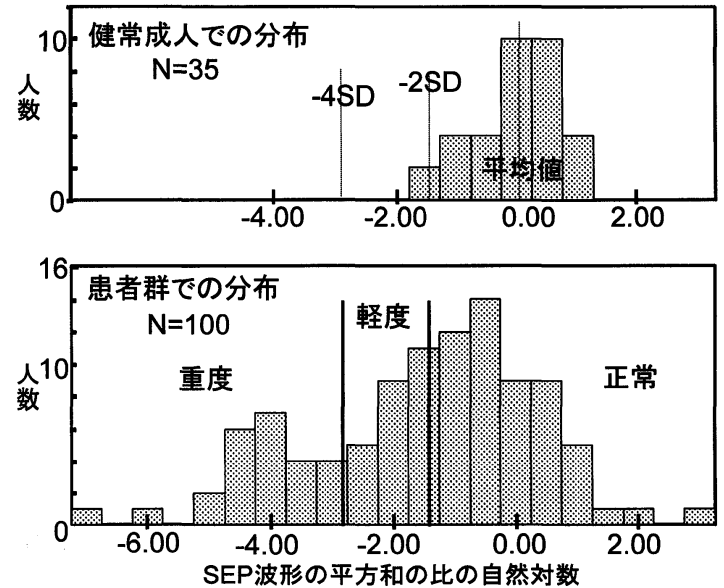

図 3 脛骨神経 SEP で計測した平方和の比の分布 上段に健常成人での脛骨神経 SEP の平方和の比の分布を, 下段に患者群での脛骨神経 SEP の平方和の比の分布を示 した，上段下段とも分布は，横軸に平方和の比の自然対数 をとり示してある．健常成人での平方和の比の自然対数の 平均は 0.02 , 標準偏差 0.71 となり, 平均から 2 標準偏差 ごとに下段に示すように患者群を正常, 軽度障害, 重度障 害と分類した。

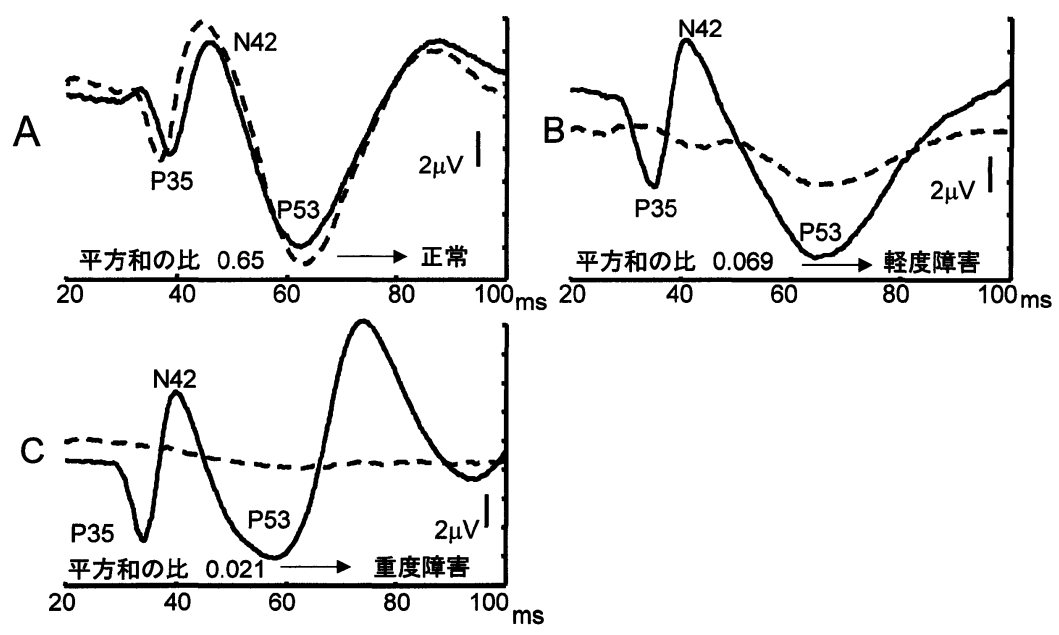

図 4 脛骨神経 SEP の障害度分類

$\mathrm{A} ， \mathrm{~B} ， \mathrm{C}$ の各波形は患者群で得られた典型的波形である.実線が健側刺激で得られた 波形を, 破線が患側刺激で得られた波形を示す. 各波形を, 平方和の比から SEP 障害 度分類にそって分類すると, A の波形は平方和の比が 0.65 で正常，B は 0.069 となり 軽度障害, C は 0.021 で重度障害となった。 
の比について，その分布の正規性および再現性を検定 するとともに，脳血管障害患者における感覚機能障害 度分類と SEP 障害度分類の関係を Spearman の順位 相関係数, およびクロス集計, 解離例から検討した。

\section{結 果}

\section{1. 下肢感覚機能}

母趾運動覚の測定結果は, 正常が 59 名, 軽度低下 が 11 名, 中等度低下が 8 名, 重度低下が 7 名, 脱失 が 15 名であった。

母趾触覚では, 正常が 62 名, 軽度低下が 17 名, 中 等度低下が 5 名, 重度低下が 9 名, 脱失が 7 名であっ た。

痛覚については, 正常が 68 名, 軽度低下は 2 名, 中等度低下が 3 名, 重度低下が 3 名, 脱失が 15 名と なった。

\section{2. 脛骨神経 SEP}

健常成人での脛骨神経 SEP から求めた平方和の比 の分布は, 正規分布とならなかったため, 平方和の比 の自然対数を求め正規化した。その結果，図 3 上段に 示した分布となり，平方和の比の自然対数の平均值は 0.02 , 標準偏差 0.71 となった，正規性を検定する Shapiro-Wilks 検定では正規性が確認された.

健常成人の SEP 波形における平方和の比の 2 施行 間の再現性は, 平方和の比そのものでは Pearsonの 相関係数が $0.82(p<0.001)$, 障害度分類では Cohen のカッパが $0.65(p<0.001)$ となり良好であったた め, 1 施行目の值をその患者の SEP 波形における障 害度として採択し，患者における SEP 波形の障害度 を定めた。

健常者群, 患者群より得られた典型的な SEP 波形 を示したのが，図4の A， B，Cの波形である，Aの 波形は平方和の比が 0.65 で正常, $\mathrm{B}$ は 0.069 となり 軽度障害, Cは 0.021 で重度障害となった。

各患者での 1 施行目の SEP 波形から求めた平方和 の比の自然対数は図 3 下段のように分布し，正常が 54 名, 軽度障害が 22 名, 重度障害が 24 名となった。 また, 患者群の健側刺激時の頂点潜時の平均值は P 35 で $40.6 \pm 3.1 \mathrm{~ms}, \mathrm{~N} 42$ で $48.9 \pm 4.0 \mathrm{~ms}, \mathrm{P} 53$ で $63.5 \pm 4.3 \mathrm{~ms}$, 振幅の平均值については P 35-N 42

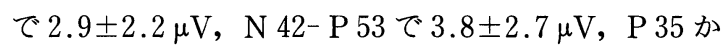
ら P 53 の健側での平方和は最小值 3.8 , 最大值 6102.6 , 中央値 257.9 , 平均值 $568.7 \pm 917.3$ であっ
た. 健側の P 35 から P 53 の潜時における患側の平方 和は最小值 0.5 , 最大值 4223.9 , 中央值 49.2 となっ た. 健常成人の右側刺激時の值と, 患者群の健側刺激 時の値を $\mathrm{T}$ 検定で比較すると, 各頂点潜時, P 35$\mathrm{N} 42$ の振幅について有意差を認めたが $(p<0.01)$, 平方和 $(p=0.726), \mathrm{N} 42-\mathrm{P} 53$ の振幅 $(p=0.503)$ については有意差を認めなかった。

\section{3. 感覚機能と SEP 障害度との関係}

SEP 障害度と評価した各感覚機能の関係を表 3 の $\mathrm{A}, \mathrm{B}, \mathrm{C}$ にクロス集計で示した。

母趾運動覚の正常例 59 例では, SEP 障害度が重度 障害である症例が 1 例あるものの, それ以外の 58 例 は，いずれも SEP 障害度が軽度または正常であった。 母趾運動覚脱失例 15 例では, SEP 重度障害例が 10 例あったが, 軽度障害 3 例, 正常も 2 例認めた。

母趾触覚の正常例 62 例では, SEP 障害度が重度で ある症例が 8 例, 軽度または正常例は 54 例であった。 母趾触覚脱失例 7 例では SEP 障害度が重度である症 例が 4 例, 正常または軽度は 3 例であった.

母趾痛覚の正常例 69 例では, SEP 障害度が重度で ある症例が 11 例, 軽度または正常が 58 例であった。 母趾痛覚脱失例 15 例では, SEP 障害度が重度が 8 例，軽度または正常が 7 例であった。

SEP 障害度分類と運動覚, 触覚, 痛覚の障害の程 度との関係を Spearman の順位相関係数でみると, 触覚との相関係数は $0.46 （ p<0.001 ） て ゙ あ る の に$ 対

表 3 SEP 障害度と運動覚 (A), 触覚 (B), 痛覚 (C) との関係

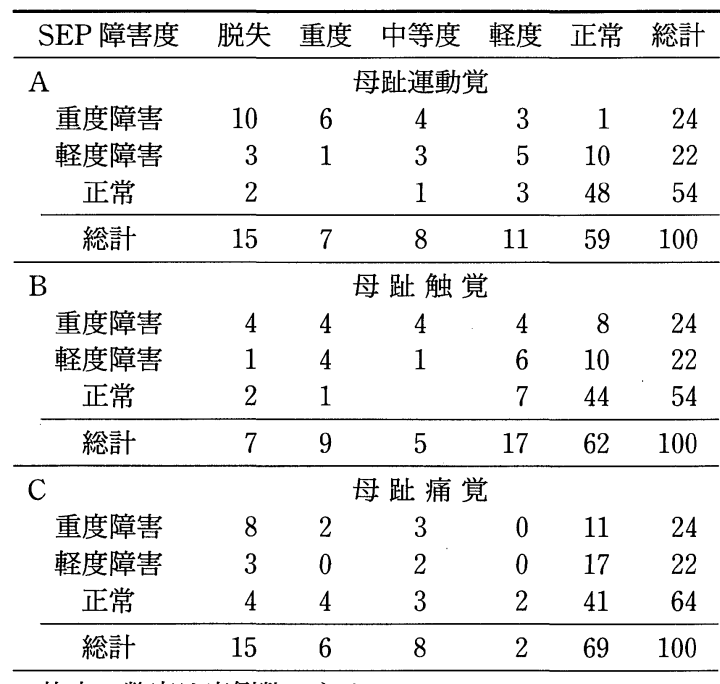

枠内の数字は症例数である. 
表 4 脳出血患者における感覚の解離例の検討

\begin{tabular}{lccc}
\hline & \multicolumn{3}{c}{ SEP 障害度 } \\
\cline { 2 - 4 } & 重度 & 軽度 & 正常 \\
\hline 触覚障害例* & & 2 & 2 \\
運動覚障害例** & 4 & 1 & 1 \\
\hline
\end{tabular}

枠内の数字は症例数である.

*触覚が脱失または重度障害で, 運動覚が正常な例

**触党が正常で, 運動賞が脱失または重度障害である 例

して, 運動覚との相関係数は $0.72(p<0.001)$ と高 い相関を示した。痛覚については，0.25（ $p=0.011 ）$ と相関は低かった。

\section{4. 病型別の感覚機能と SEP の関係}

脳梗塞 42 例において, 触覚, 運動覚, 痛覚と SEP 障害度分類との相関をみると, 触覚については 0.71 $(p<0.001)$, 運動覚については $0.66(p<0.001)$ と, ともに高い值であった。しかしながら，痛覚において は $0.27 （ p=0.085 ）$ と有意な相関を認めなかった.

脳出血 55 例での, 触覚, 運動覚, 痛覚についての SEP 障害度分類との相関をみると, 運動覚とでは $0.68 （ p<0.001 ）$ と高い相関を示した。しかし, 触 覚では $0.26(p=0.055)$, 痛覚では $0.23(p=0.092)$ と有意な相関を認めなかった。

触覚と運動覚の障害の程度が解離した 10 例の脳出 血患者について SEP 障害度との関係を見た。触覚が 正常で，運動覚が脱失または重度障害例は 6 例あり， いずれも視床出血であった。このうち，5例が患側刺 激の SEP で明らかな頂点を認めなかった。一方, 触 覚が脱失または重度障害で, 運動覚が正常な例が 4 例 あり， 3 例が被壳出血，残り 1 例が視床出血であっ た。視床出血例では明らかな頂点は認められなかった が，被殼出血例ではいずれも，P 35，N 42，P 53 の 頂点が認められた。これらの解離した例を, SEP 障 害度分類により分類すると, 触覚が脱失または重度障 害で，運動覚が正常な例では，SEP 障害度分類が軽 度および正常のものしかいないのに対して, 触党が正 常で運動覚が脱失または重度障害である6 例ではその 内の 4 名が重度であった（表 4).

\section{考 察}

\section{1. 下肢の感覚機能評価}

脳血管障害患者の感覚機能に関して運動覚, 触覚, 痛覚の評価を行った。運動覚はこれまでの評価で
SEP の障害との関係が報告されていること ${ }^{1 \sim 6)}$ ，触覚 は運動覚と同様の内側毛帯系の感覚であることから計 測に含めた. 内側毛帯系の感覚としては, 運動覚や位 置覚以外にも触圧覚, 振動覚と二点識別覚がある.し かし，振動覚の受容器は皮虐の触圧覚の受容器と同 じ7であり, 触圧覚で代表させた。二点識別覚につい ては, 予備実験の段階で, 患者群の健側での值が健常 成人の值と大きく異なっていたため, 本実験からは除 外した. また, 内側毛帯系以外の感覚の代表として痛 覚を含めた。

運動覚の評価は, 他動的に母趾 MP 関節を底背屈 させることにより行った. 背屈, 底屈ともどちらも正 確に答えられた段階で評価したが，症例の中には，運 動の方向により知賞の程度が異なっていると感じられ る例も認められた。感覚野レベルでは，運動の方向に より発火する細胞が異なることが報告されておうう 運動の角度だけでなく, 運動の方向についても今後検 討する必要があると思われた。

触覚の評価にはセメス・ワインスタイン・モノフィ ラメント知覚テスターを使用した。簡便で再現性も高 い検査とされているが9), 母趾の触覚の障害の程度を 評価した文献は皆無であり, 健常成人から計測のため

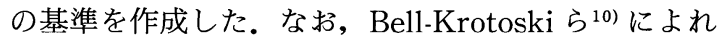
ば母趾腹側での正常值はないものの, 健常成人 92 名 において，3.61 のフィラメントで，98９9\%の人が, 2.83 のフィラメントでは $74 \sim 83 \%$ の人が知覚したと しており, 本研究で閾值の平均が 3.34 となったのと ほぼ一致していた。

痛覚の評価には, 痛覚は $1 \mathrm{~g}$ から $20 \mathrm{~g}$ まで測れる 定量知覚針 ${ }^{\circledR}$ を使用し，母趾先端部で計測した。この 評価法も, 文献的に母趾での評価基準がなかったた め, 健常成人より.作成した。この検査器機は, 針の上 に 1 20 g の重がかかるようになっており，段階的に 痛覚の評価が可能である。しかし構造上，針が皮膚に 対して垂直にならない限り，正しい測定が困難であ り，患者が腹臥位をとりにくいという制限から，母趾 の指腹ではなく, 母趾先端で計測した。

予備実験の対象と健常成人の年齢は平均年齢 $29 \pm$ 7.2 歳と患者群の $59.3 \pm 10.5$ 歳にくらべ若年であっ たが, 患者群健側での触覚の平均值は $3.53 \pm 0.54$ $\log _{10} F$ で, $t$ 検定では健常成人の平均値と有意差を 認めなかった $(p=0.105)$.また, 痛覚についても患 者群健側での平均值は $5.78 \pm 6.52 \mathrm{~g}$ で有意差を認め 
ず（ $p=0.146 ）$, 患者群と健常成人の年齢差の影響は ないものと思われた。

\section{2. 脛骨神経 SEP の障害程度評価方法}

才藤は ${ }^{11)}, 106$ 名の脳血管障害患者を対象とした研 究で, 上肢の正中神経 SEP と感覚機能を比較した場 合, 中枢伝導時間や単独の N 20 の振幅のみでは感覚 機能の有効な指標とはならず，中潜時 SEP の N 18 以降の波形により分類した波形障害度分類が, 感覚機 能と高い相関があることを示した。

今回, 下肢の脛骨神経 SEP の中潜時波形でも, 正 中神経 SEP の分類と同様に, 特定の頂点の有無など 波形の特徵により分類することを考えた. しかし, 脛 骨神経 SEP では図 4 A のように左右の刺激による波 形がほぼ等しいものから，頂点がまったく認められな い図 $4 \mathrm{C}$ まで, 全体の振幅が連続的に移行しており, 波形の形状から SEP の障害の程度を分類することは 困難であった。また，P 35-N 42 や N 42-P 53 の振幅 で分類することも，ぞれぞれの健常成人での平均值が $4.1 \pm 2.1 \mu \mathrm{V}, 4.1 \pm 1.9 \mu \mathrm{V}$ であり, 標準偏差が大き いことから，平均值と標準偏差から患者群を分類する ことは困難であったＰ３5 から P 53 の平方和につい ても平均值が $616.0 \pm 580.7$ と標準偏差が大きく同様 であった。頂点潜時および振幅比については, 頂点が 不明瞭な場合の扱いが恣意的にならざるを得ず，自動 的に分類するには適当な分類法ではなかった。そこ で，健側刺激時の SEP 波形で P 35 から P 53 までの 区間での平方和を求め，それに対応して同じ潜時での 患側刺激波形の平方和との比を求めることで，健側刺 激時の波形と患側刺激時の波形を比較する指標とし た. 健常成人の平方和の比は, 自然対数を求めること で正規化でき，平方和の比の自然対数の平均值は $0.02 \pm 0.71$ となったので, 平均値から 2 標準偏差ご とに正常, 軽度障害, 重度障害とし, 患者群で得られ た波形を分類した。

分析の対象とした範囲を P 35 から P 53 とした。理 由は, P 35 と N 42 の起源が大脳の足感覚野にあるこ とが分かっており ${ }^{12)}$, この 2 つの頂点の振幅を含める ためである。

SEP 障害度分類の問題点として, 極端にそれぞれ の頂点潜時が異なる場合, 平方和の比が低下する可能 性があったが，今回の症例では，そのような例は認め られなかった。また，健側刺激の波形で振幅が小さい 場合, 患側刺激時のアーチファクトや基線の傾きがよ
り大きく評価され，患側刺激時の波形で明らかな頂点 が認められない場合でも, 平方和の比が大きくなり, SEP 障害度がより軽度に評価される可能性がある。 そのような, 再現性のある頂点が認められないのにも かかわらず，障害度が正常または軽度障害と診断され た例は 7 例に留まった。

SEP の予備実験で対象とした健常成人の平均年齢 $29.0 \pm 7.2$ 歳と患者群に比べ若かったが, 健常成人の 右側刺激時の平方和と患者健側刺激時の平方和に $t$ 検 定で有意差を認めず，SEP 障害度分類には影響しな いと思われた。

\section{SEP 障害度と感覚障害の関係}

患者の SEP 障害度分類と運動覚, 触覚, 痛覚の障 害の程度との関係を Spearman の順位相関係数で表 すと，運動覚との相関係数は 0.73 , 触覚とでは 0.46 , 痛覚で 0.23 となり, 運動覚との相関がもっとも高か った。これはこれまでの臨床的な報告 ${ }^{5,6)}$ と一致する ものである。

脳梗塞と脳出血の SEP 障害度分類と各感覚機能と の相関関係 は, 痛覚（脳梗塞例 0.27 , 脳出血例 0.23 ), 運動覚（脳梗塞例 0.66 , 脳出血例 0.68 ）につ いては同じ傾向を示したが，触覚については脳梗塞例 の 0.71 に対して, 脳出血例では 0.26 と異なってい た.これは, 脳梗塞例では, 病巣が広いため, 同じ内 側網体系の感覚である運動覚と触覚が同時に障害され ることが多く, 一方, 脳出血の場合には病巣が限局さ れるため, 運動覚と触覚が解離しやすいためと考えら れた。

また, 運動覚と触覚の障害が解離した脳出血患者の 検討では，運動覚が重度に障害されているものの, 触 覚が保たれている場合には, SEP 波形が重度に障害 されていた。

これらの結果より，脳血管障害患者において，脛骨 神経 SEP の障害の程度と運動賞の障害の程度とに強 い関連があると結論づけられた。

脛骨神経 SEP の形成における筋求心性神経活動と 皮膚求心性神経活動の役割については, 筋求心性神経 活動が大脳皮質での脛骨神経 SEP 波形の形成に大き な役割を果たしていることが，マイクロニューログラ ムを使った実験 ${ }^{13,14)}$ から示されている. 一方, 運動 覚などのいわゆる筋感覚の形成については，筋紡鍾の 一次終末や二次終末からの求心路の役割がもっとも大 きく, 皮虐や関節包からの求心路も少なからず関係し 
ているとする報告15) もあり，脛骨神経 SEP の障害度 分類と母趾運動覚の障害程度が強く相関した今回の実 験結果と合致していると考えられた。

\section{4. 運動覚の評価法としての SEP 障害度分類の 検討}

運動覚と脛骨神経 SEP の障害度分類が高い相関を 示したことから，脛骨神経 SEP の障害度分類から運 動覚障害に対する感度と特異度を算出した。脛骨神経 SEP に異常を認める場合（SEP 障害度分類で正常以 外の場合）に，母趾運動覚の障害（運動覚の評価基準 で正常以外）を検出できるかという観点から求める と，感度は $85 \%$ ，特異度は $81 \%$ となり，SEP 検査は 運動覚障害の有無を評価するための有効な検査法であ ることが分かった。また，脛骨神経 SEP に重度の障 害を認める場合（SEP 障害度分類で重度障害の場合） に母趾運動覚の重度の障害（運動覚の評価基準で重度 低下または脱失）を検出できるかという観点から求め ると, 感度は $73 \%$, 特異度は $90 \%$ となり, SEP 検査 は単に運動覚の異常の有無のみならず, 運動覚障害の 程度の検出にも有用であることが分かった。

以上より, SEP 検査による運動覚の客観的な評価 は, 脳血管障害患者の評価に利用でき, 予後予測を行 う場合の臨床所見の 1 つとして利用できる可能性が示 唆された。

稿を終えるに当たり，本研究に関し，ご指導，ご校 閲をいただきました慶應義塾大学医学部リハビリテー ション医学教室千野直一教授に深謝いたします。ま た，本研究の直接のご指導をいただきました藤田保健 衛生大学リハビリテーション医学講座才藤栄一教授, 分析法について貴重なご助言をいただきました慶應義 塾大学理工学部情報工学科富田豊教授に感謝いたしま す.

本論文の主旨は, the 10th International Congress of Electromyography and Clinical Neurophysiology （Kyoto）で発表した.

\section{文献}

1) Halliday AM, Wakefield GS: Cerebral evoked potentials in patients with dissociated sensory loss. J Neurol Neurosurg Psychiatry 1963; 26 : 211-219
2) Giblin DR: Somatosensory evoked potentials in healthy subjects and in patients with lesions of the nervous system. Ann NY Acad Sci 1964 ; 112 : 93142

3) Anziska B, Crracco RQ: Short latency somatosensory evoked potentials: studies in patients with focal neurological diseases. Electroencephalogr Clin Neurophysiol 1976; $41: 595-608$

4) Shibasaki H, Yamashita Y, Tsuji S: Somatosen sory evoked potentials. Diagnostic criteria and abnormalities in cerebral lesions. J Neurol Sci 1977; 34: 427-439

5) Yokota $T$, Hirose $K$, Tsukagoshi $H$, Tanabe $H$ : Somatosensory evoked potentials in patients with selective impairment of position sense versus vibration sense. Acta Neurol Scand 1991; 84 : 201-206

6) Hirose K, Sugawara Y, Ito H, Onodera K, Sato C, Kogure K: Somatosensory evoked potentials following stimulation of median and tibialnerves in patients with localized intracerebral hemorrhage: correlations with clinical and CT findings. J Neurol Sci $1991 ; 102$ : 172-178

7) 田崎京二, 小川哲朗 編: 感覚の生理学, 新生理学大系 9, 医学書院, 東京, 1989 ; pp 90-351

8) Prud'homme MJL, Kalaska JF : Proprioceptive Activity in primate primary somatosensory cortex during activity arm reaching movement. J Neurophysiol $1994 ; 72: 2280-2301$

9) Bell-Krotoski JA, Buford WL: The force/time relationship of clinical used sensory testing instruments. Hand Therapy 1997 ; 10 : 297-309

10) Bell-Krotoski JA, Fess EE, Figarola JH, Hiltz D: Threshold detection and Semmes-Weinstein monofilaments. Hand Therapy $1995 ; 8$ : 155-162

11）才藤栄一，木村彰男，千野直一，沢 俊二：脳血管障害 患者に扔ける体性感覚誘発電位一感覚障害・運動麻痺 との関係. リ八医学 $1989 ; 26: 141-147$

12）高橋 宏, 石島武一：皮質上下記録および大脳半球間 裂記録による後脛骨神経刺激 SEP 起源の推定. 臨床脳 波 1993；35：221-225

13) Gandevia SC, Burke D : Projection of thenar muscle afferents to frontal and parietal cortex of human subjects. Electroencephalogr Clin Neurophysiol $1990 ; 177: 353-361$

14) Burke D, Gandevia SC: Interfering cutaneous stimulation and the muscle afferent contribution to cortical potentials. Electroencephalogr Clin Neurophysiol $1988 ; \mathbf{1 7 0}$ : 118-125

15) Matthew PBC: Proprioceptors and their contribution to somatosensory mapping : complex messages require complex processing. Can J Physiol Pharmacol $1988 ; 66: 430-438$ 